\title{
DIPLOMASI EKONOMI INDONESIA DI DALAM REZIM EKONOMI G20 PADA MASA PEMERINTAHAN JOKO WIDODO
}

\author{
Wiwiek Rukmi Dwi Astuti ${ }^{1}$, Laode Muhamad Fathun ${ }^{2}$ \\ ${ }^{1}$ Program Studi Hubungan Internasional, Universitas Pembangunan Nasional Veteran Jakarta, Indonesia; \\ wiwiek.rukmi@upnvj.ac.id \\ ${ }^{2}$ Program Studi Hubungan Internasional, Universitas Pembangunan Nasional Veteran Jakarta, Indonesia; \\ laodemuhammadfathun@upnvj.ac.id
}

\begin{abstract}
This research answers how Indonesia's economic diplomacy strategy is in the G20 global economic forum. This research uses a qualitative approach, literature study and the concept of economic diplomacy to analyze the data. The results show that Indonesia's diplomacy strategy which is implemented through the national strategic plan in the G20 forum forms a pattern of economic diplomacy regarding trade, commerce and finance. The novelty of this research is to prove the character of Indonesia's economic diplomacy in the G20 forum as a country that is in an evolving cluster. External economic management and policies through coordination between ministries; trade promotion which is an integration of political and economic efforts; the Ministry of Foreign Affairs to actively promote investment, particularly through the ambassador and BKPM. The role and diplomacy of Indonesia's economy is a commitment to maintaining national, regional and international economic stability as a form of national and international interests.
\end{abstract}

Keywords: economic diplomacy, economic interests of Indonesia, G20

\begin{abstract}
Abstrak
Penelitian ini menjawab bagaimana strategi diplomasi ekonomi Indonesia di dalam forum ekonomi global G20. Penelitian ini menggunakan pendekatan kualitatif, studi kepustakaan serta konsep diplomasi ekonomi untuk menganalisis data. Hasil penelitian menunjukkan bahwa strategi diplomasi Indonesia yang diimplementasikan melalui rencana strategis nasional dalam forum G20 membentuk pola diplomasi ekonomi menyangkut perdagangan, komersial dan finansial. Kebaruan dari penelitian ini adalah membuktikan akan karakter diplomasi ekonomi Indonesia di forum G20 sebagai negara yang berada dalam kluster evolving. Manajemen ekonomi eksternal dan kebijakan melalui koordinasi antar kementerian; promosi perdagangan yang merupakan integrasi dari upaya politik dan ekonomi; promosi investasi secara aktif oleh Kemlu, khususnya melalui duta besar dan BKPM. Peran dan diplomasi ekonomi Indonesia ini merupakan komitmen untuk menjaga stabilitas ekonomi nasional, regional dan internasional sebagai bentuk kepentingan nasional dan kepentingan internasional.
\end{abstract}

Kata Kunci: diplomasi ekonomi, G20, kepentingan ekonomi Indonesia 


\section{Pendahuluan}

Revolusi teknologi dan liberalisasi perdagangan dunia telah menciptakan global society dalam struktur internasional, sehingga peristiwa krisis keuangan global pada tahun 2007 telah menciptakan dampak negatif baik terhadap negara maju maupun negara berkembang. Krisis keuangan global terjadi karena kurangnya koordinasi internasional yang responsif menghadapi krisis dan regulasi sektor keuangan yang kurang akuntabel (excessive risk taking). Krisis keuangan global menyebabkan negara maju terpuruk sektor keuangannya dan berdampak ke sektor riil, sementara negara berkembang mendapatkan imbasnya dalam bidang perdagangan dan investasi asing (Wibisono, 2011). Dari peristiwa ini terbentuklah gagasan kelompok G-20 Leaders Meeting untuk menyelenggarakan Konferensi Tingkat Tinggi (G20 Summit) bagi para pemimpin atau kepala negara kelompok G20 di Washington DC tanggal 15 November 2008

Anggota G20 mulai mengoordinasikan tindakan bersama melalui proses asesmen yang mengidentifikasi tujuan bersama untuk ekonomi global, kebijakan yang diperlukan untuk mencapainya, dan kemajuan menuju pemenuhan tujuan bersama tersebut. Pada masa Presidensi Tiongkok tahun 2016, anggota G20 merumuskan Enhanced Structural Reform Agenda (ESRA), yang mengidentifikasi sembilan bidang prioritas untuk struktural termasuk mempromosikan pertumbuhan pembangunan inklusif. Bagaimanapun, reformasi struktural merupakan faktor penting pendorong pertumbuhan untuk jangka menengah dan panjang. Fakta bahwa PDB per kapita di negara-negara G20 berada pada jalur pertumbuhan yang lebih rendah daripada sebelum krisis keuangan global menjadi perhatian utama G20. Meskipun demikian, tingkat pekerjaan mengalami kenaikan hampir mendekati level sebelum krisis. Di beberapa negara, seperti Indonesia, Jerman, Arab Saudi dan Turki, tingkat pekerjaan saat ini bahkan lebih tinggi daripada sebelum krisis keuangan global (OECD, 2019).

\section{Gambar 2 - Tingkat pekerjaan mendekati level sebelum krisis}

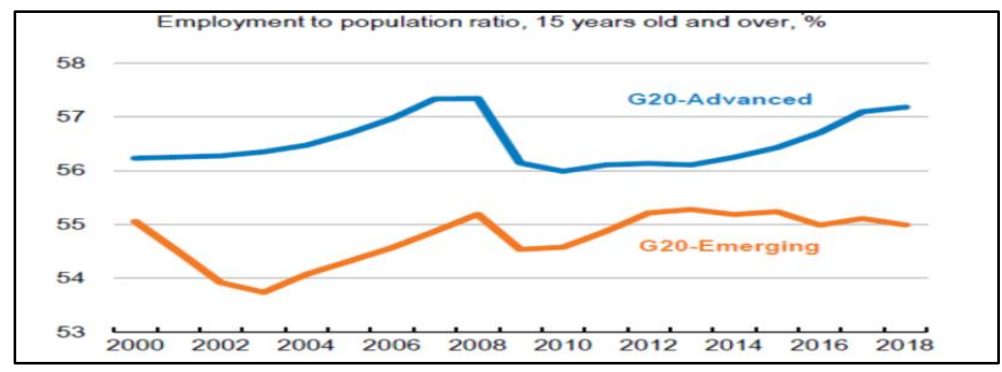

Sumber: (OECD, 2019) 
Berbicara dalam konteks Indonesia, sejak KTT Washington yang diadakan sebagai tanggapan terhadap krisis keuangan global tersebut, G20 telah menjadi mimbar dialog di antara para kepala negara dan pemerintah dari 20 negara. Sejak saat itu pula, Presiden Indonesia Susilo Bambang Yudhoyono (SBY) dan Joko Widodo (Jokowi) telah menghadiri KTT G20 secara berkala. Kontribusi Indonesia dalam menyusun kebijakan-kebijakan terkait pembangunan ekonomi dalam G20 selama ini menunjukkan kesungguhan dan komitmennya. Seperti pada tahun 2010, sejumlah gagasan inti dari Indonesia menjadi landasan dalam Seoul Development Consensus for Shared Growth (Hornung, 2017). Melalui Konsensus Seoul disepakati rekonstruksi voting power di IMF sehingga memihak kepada negara-negara berkembang, dan juga mendirikan fondasi untuk mereformasi agenda kebijakan pembangunan global. Selain memperjuangkan kepentingan nasionalnya, Indonesia juga melihat dirinya sebagai perwakilan dari negara-negara berkembang dan berkomitmen untuk mengadvokasi agenda pembangunan sebagai prioritas dalam proses G20. Indonesia sebagai perwakilan dari negara berkembang, bercita-cita untuk menciptakan kesepakatan yang lebih adil dan sejajar dan saling menguntungkan, termasuk dalam mendorong diplomasi ekonomi tanpa menghilangkan esensi solidaritas sesama negara berkembang.

Mengenai keanggotaan Indonesia di G20, Hermawan (2015) menyebutkan bahwa banyak kebijakan kontroversial dari Indonesia karena menjadi anggota G20. Keterlibatan Indonesia dalam forum tersebut dianggap akan menghambat pertumbuhan ekonomi Indonesia terutama hambatan tarif. Fakta di lapangan ditemukan bahwa ekspor ikan tuna Indonesia bisa mencapai 700 juta USD, namun setelah mendapat tarif pendapatan justru berkurang menjadi 105 juta USD. Oleh karena itu, perlu disadari bahwa G20 juga bukan dewa (pengabul permintaan) dan malaikat (pembawa kebaikan), melainkan sebuah forum internasional yang tentunya tidak bisa memberikan segalanya tetapi bisa memberikan manfaat dalam berbagai bidang ekonomi. Artinya G20 bukan "dokter" yang bisa mendiagnosa penyakit tertentu melalui resep. G20 hanya sebagian kecil dari pertemuan global dengan keterpilihan Indonesia dari 193 negara di dunia merupakan bukti komitmen Indonesia untuk menjaga kepentingan nasional di bidang ekonomi dan juga kepentingan dan stabilitas ekonomi global. G20 sebagai sebuah forum pasti ada kekurangan makanya dalam RPJMN 2015-2019 Indonesia merancang strategi-strategi percepatan yang disebut quickwins untuk mencapai hal positif di G20. Adapun rancangan tersebut adalah perbaikan infrasruktur, perlindungan tenaga kerja, pengurangan hambatan tarif perdagangan dan sejumlah kebijakan 
lainya. Oleh sebab itu, sebagai negara besar keterlibatan Indonesia akan sangat memiliki kontribusi dalam ekonomi politik internasional.

Menurut Sushanti (2019), setidaknya terdapat dua hal penting dalam keterlibatan Indonesia di forum G20, yaitu pertama, sebagai negara yang berusaha untuk mencocokkan standar kualitas produk yang sesuai dengan konsumen global. Pada poin ini kesempatan Indonesia untuk mendapatkan masukan-masukan terkait produk-produknya yang diekspor ke luar negeri. Kedua, Indonesia juga mendapatkan kesempatan pasar yang luas, transfer teknologi serta keterbukaan kerja sama. Indonesia yang selalu menjadi vital poin dalam menjaga stabilitas kawasan regional akan sangat penting terlibat dalam forum G20. Selain itu, keterlibatan Indonesia juga didukung oleh kepentingan posisi daya tawar negosiasi yang tinggi, karena dengan berada dalam forum global, keputusan Indonesia tentu akan menentukan apalagi bagi negara-negara berkembang. Artinya Indonesia bisa dikatakan sebagai representasi negara berkembang dalam forum multilateral baik yang membahasas tentang isu perdagangan di WTO, isu finansial di IMF dan isu lainya yang relevan.

Masa pemerintahan Presiden Indonesia Susilo Bambang Yudhoyono dikenal menjalankan outward-looking policy sehingga eksistensi Indonesia di mata internasional menjadi begitu penting. Namun pada pemerintahan Presiden Jokowi, Indonesia lebih kenal dengan pemerintahan inward-looking policy. Meskipun demikian, Kabinet Kerja yang menjadi pasukan dalam kepemerintahan Jokowi mengemukakan bahwa Indonesia senantiasa berkomitmen dalam beragam kerja sama multilateral, termasuk G20. Dalam studi mengenai G20 ini sendiri, negara-negara emerging economies dianggap sebagai representatif dari kawasan masing-masing, seperti Indonesia sebagai negara yang mampu mewakili kepentingan negara-negara berkembang khususnya di kawasan Asia Tenggara. Oleh karena itu, penelitian ini bermaksud untuk menjawab strategi diplomasi ekonomi Indonesia dalam forum ekonomi global G20.

\section{Konsepsi Diplomasi Ekonomi}

Paradigma neoliberal mengemukakan bahwa ekonomi beserta rezim yang mengatur perekonomian dunia termasuk kepada arus utama untuk menciptakan interdependensi dengan aktor lainnya. Dengan asumsi dasar bahwa ekonomi dapat menjawab sebagian besar kepentingan negara, sehingga konflik pun dapat ditekan. Kaum neoliberal percaya bahwa melalui sistem dunia yang 
anarki, akan muncul peluang yang besar untuk melakukan kerja sama dalam bentuk perdagangan maupun interdepedensi di bidang ekonomi (Baldwin, 1993).

Bishop (2019) menyebutkan bahwa seabad setelah krisis ekonomi global tahun 2008-2009, banyak muncul patologi dalam fungsi dan praktik ekonomi global. Krisis tersebut menjelaskan bahwa masyarakat tidak dapat sepenuhnya menangani krisis yang menimpa mereka, stagnansi modal, dan meningkatnya ketidaksetaraan dan kemiskinan. Jessop (2016) menyebutkan bahwa momentum krisis ekonomi global 2008-2009 telah diinterpretasikan sebagai krisis dari neoliberalisme (crisis of) ketimbang krisis dalam neoliberalisme (crisis in). Sehingga, intervensi negara secara masif telah menciptakan neoliberal 'business as usual' kembali seperti semula. Bishop juga menyatakan bahwa meskipun negara-negara maju mengalami kemunduran, secara paradoks, mereka tetap sangat tangguh (resilient), dan melanjutkan kepemimpinan dan performanya sebagai negara maju. Sebagaimana dalam tatanan neoliberal, pada G20, terdapat komitmen yang mendalam terhadap multilateralisme pada negara anggota dan lembaga yang berada dalam lingkaran kerja sama yang lebih luas, untuk menyokong tata kelola ekonomi global.

Selanjutnya, pemikiran mengenai diplomasi ekonomi fokus pada peran aktor diplomatik dan hubungan yang terjalin, aktivitas, dan institusi di mana para aktor tersebut bekerja dalam menciptakan dan mengelola kesalingtergantungan ekonomi (Lee \& Hocking, 2010). Diplomasi ekonomi dilihat sebagai alat untuk mengejar dan mencapai keamanan ekonomi di dalam sistem internasional yang anarkis. Melalui konsep diplomasi ekonomi dengan paradigma neoliberal, menuntut negara memahami pola interaksi ekonomi internasional yang berbasis pada kepentingan ekonomi. Dengan konsep ini akan berdampak pada rekomendasi model diplomasi, negosiasi negara dalam melakukan interaksi di level internasional. Konsep ini menyediakan manajemen tata kelola hubungan eksternal, manajemen kebijakan, pola perdagangan, investasi dan fokus keterlibatan aktor lain dalam diplomasi ekonimi. Dengan demikian, konsep ini dianggap komprehensif dalam memetakan pola diplomasi ekonomi Indonesia di forum G20.

Kishan S. Rana (2007) membagi tipologi diplomasi ekonomi menjadi empat jenis yakni traditional, niche-focused, evolving, dan innovative. Perbedaan dari masing-masing tipologi dapat dilihat pada tabel di bawah ini. 
Tabel 1 - Tipologi Diplomasi Ekonomi

\begin{tabular}{|c|c|c|c|c|}
\hline & Traditional & Niche-Focused & Evolving & Innovative \\
\hline $\begin{array}{l}\text { Manajemen } \\
\text { Ekonomi } \\
\text { Eksternal }\end{array}$ & $\begin{array}{l}\text { Dijalankan oleh } \\
\text { kementerian ekonomi dan } \\
\text { perdagangan; minim } \\
\text { keterlibatan Kemlu }\end{array}$ & $\begin{array}{l}\text { Promosi yang } \\
\text { focus pada bidang } \\
\text { yang } \\
\text { diidentifikasi }\end{array}$ & $\begin{array}{l}\text { Adanya koordinasi } \\
\text { antara kementerian } \\
\text { perdagangan dan } \\
\text { Kemlu; persaingan } \\
\text { dapat terjadi }\end{array}$ & $\begin{array}{l}\text { Kesepakatan kerja } \\
\text { sama }\end{array}$ \\
\hline $\begin{array}{l}\text { Manajemen } \\
\text { Kebijakan }\end{array}$ & $\begin{array}{l}\text { Peran terbatas bagi Kemlu, } \\
\text { kadang terjadi } \\
\text { miskoordinasi di level } \\
\text { taktis }\end{array}$ & $\begin{array}{l}\text { Koordinasi } \\
\text { internal yang baik }\end{array}$ & $\begin{array}{l}\text { Inter-ministry atau } \\
\text { koordinasi di tingkat } \\
\text { kabinet }\end{array}$ & $\begin{array}{l}\text { Manajemen yang } \\
\text { terinstitutionalisasi, } \\
\text { strong teamwork }\end{array}$ \\
\hline $\begin{array}{l}\text { Peran Non- } \\
\text { State Actor }\end{array}$ & $\begin{array}{l}\text { Episodic, terdgantung dari } \\
\text { personality }\end{array}$ & Variabel & $\begin{array}{l}\text { Prosedur baru, strong } \\
\text { networking }\end{array}$ & $\begin{array}{l}\text { Harmonisasi } \\
\text { dengan seluruh } \\
\text { stakeholders }\end{array}$ \\
\hline $\begin{array}{l}\text { Bantuan } \\
\text { Economi: } \\
\text { Recipient }\end{array}$ & $\begin{array}{l}\text { Ditangani instansi bidang } \\
\text { ekonomi, jarang } \\
\text { berkoordinasi dengan } \\
\text { Kemlu }\end{array}$ & $\begin{array}{l}\text { Koordinasi } \\
\text { terbatas }\end{array}$ & $\begin{array}{l}\text { Networking antara } \\
\text { instansi pengelola } \\
\text { bantuan dan Kemlu }\end{array}$ & $\begin{array}{l}\text { 'Graduated' di luar } \\
\text { bantuan yang } \\
\text { diterima }\end{array}$ \\
\hline $\begin{array}{l}\text { Bantuan } \\
\text { Economi: } \\
\text { Donor }\end{array}$ & $\begin{array}{l}\text { Kecil menjadi donor } \\
\text { bantuan }\end{array}$ & $\begin{array}{l}\text { Kecil menjadi } \\
\text { donor bantuan }\end{array}$ & $\begin{array}{l}\text { Program modest, } \\
\text { biasanya meliputi } \\
\text { kerjasama teknis }\end{array}$ & $\begin{array}{l}\text { Program yang } \\
\text { diperluan, } \\
\text { dijalankan oleh } \\
\text { Kemlu bekerja } \\
\text { sama dengan } \\
\text { instansi promosi } \\
\text { perdagangan }\end{array}$ \\
\hline $\begin{array}{l}\text { Promosi } \\
\text { Perdagangan }\end{array}$ & $\begin{array}{l}\text { Sering dilaksanakan } \\
\text { instansi perdagangan di } \\
\text { luar kendali Kemlu }\end{array}$ & $\begin{array}{l}\text { Fokus terbatas } \\
\text { pada promosi } \\
\text { perdagangan di } \\
\text { luar area bidang }\end{array}$ & $\begin{array}{l}\text { Perjanjian kerja } \\
\text { sama, sering } \\
\text { merupakan integrasi } \\
\text { dari upaya politik } \\
\text { dan ekonomi } \\
\end{array}$ & $\begin{array}{l}\text { Aktivitas yang } \\
\text { terkoordinasi } \\
\text { dengan baik, model } \\
\text { peran dalam } \\
\text { jangkauan aktivitas }\end{array}$ \\
\hline $\begin{array}{l}\text { Promosi } \\
\text { Investasi }\end{array}$ & $\begin{array}{l}\text { Ditangani instansi } \\
\text { domestic, peran terbatas } \\
\text { dari sistem diplomasi }\end{array}$ & $\begin{array}{l}\text { Penggunaak aktif } \\
\text { dari jaringan } \\
\text { kedutaan }\end{array}$ & $\begin{array}{l}\text { Kemlu dan kedutaan } \\
\text { bekerja secara aktif } \\
\text { dengan instansi di } \\
\text { dalam negeri, sering } \\
\text { berdasarkan inisiatif } \\
\text { individu }\end{array}$ & $\begin{array}{l}\text { Upaya tim yang } \\
\text { kuat, berdasarkan } \\
\text { pembagian peran } \\
\text { instansi }\end{array}$ \\
\hline $\begin{array}{l}\text { Peran } \\
\text { Diplomasi } \\
\text { Regional }\end{array}$ & Biasanya reaktif & $\begin{array}{l}\text { Fokus pada } \\
\text { bidang yang } \\
\text { diinginkan }\end{array}$ & Aktif & $\begin{array}{l}\text { Inovatif, exploitasi } \\
\text { dari potensi kerja } \\
\text { sama }\end{array}$ \\
\hline
\end{tabular}

Sumber: (Rana, 2007)

Kluster menurut Rana di atas ditetapkan berdasarkan pengalaman kolektifnya dalam mengamati 130 negara berkembang di G-77. Kluster traditional merupakan negara yang tertambat dalam metode konvensional, dengan menerapkan perubahan yang lambat. Niche-focused merupakan negara yang telah mengidentifikasi bidang strategis, lalu memfokuskan tindakan pada bidang yang dipilih itu. Evolving adalah kluster negara yang telah mengembangkan dan menyesuaikan diri dengan peluang baru, disertai perubahan struktural dan tindakan yang jelas. Terakhir, yaitu innovative adalah negara yang bergerak ke garis depan dengan teknik mutakhir dan 
reformasi berkelanjutan. Meski tidak ada dikotomi yang tegas antara masing-masing jenisnya, tipologi ini setidaknya dapat dijadikan gambaran awal untuk mengklasifikasi dan mengidentifikasi tipe diplomasi ekonomi yang dijalankan oleh berbagai negara.

\section{Metode Penelitian}

Penelitian ini menggunakan pendekatan kualitatif. Objek penelitian difokuskan pada keikutsertaan Indonesia dalam forum G20 di bawah kepemimpinan Presiden Jokowi. Untuk menjelaskan hal tersebut, tulisan ini menggunakan konsep diplomasi ekonomi dengan paradigma neoliberal sebagai sudut pandang analisis kasus. Data dalam tulisan ini dikumpulkan melalui studi kepustakaan (secondary sources). Dalam penelitian kualitatif, teori akan menjadi panduan dalam mencari data dan interpretasi data-data tersebut. Dikarenakan pokok permasalahan penelitian bersifat dinamis dan kompleks, maka dalam proses penelitian bermaksud memahami situasi secara mendalam dan menghasilkan rekomendasi-rekomendasi yang berguna.

\section{Kepentingan Ekonomi Indonesia dalam Rezim Ekonomi G20}

Sistem internasional yang anarki mendorong negara untuk mencari cara menghadapi ketidakamanan. Melalui koordinasi dan kolaborasi, negara tetap menemui kesulitan untuk bekerja sama di bawah sistem yang anarki. Oleh karena itu, untuk memfasilitasi kerja sama, negara-negara menciptakan institusi internasional (Reus-Smit \& Snidal, 2008). Indonesia tentu termasuk sebagai negara yang menginginkan keamanan dalam menjalin hubungan luar negeri dalam sistem internasional. Presiden Jokowi (2014-2019) menetapkan lima arah politik luar negeri Indonesia, antara lain: 1) penanganan perbatasan; 2) pemantapan peran Indonesia di ASEAN; 3) penguatan diplomasi ekonomi; 4) peningkatan kualitas perlindungan hak dan keselamatan warga negara/bahan hukum Indonesia (WNI/BHI) di luar negeri khususnya perlindungan terhadap tenaga kerja Indonesia; dan 5) pemantapan peran Indonesia dalam kerja sama global (Kementerian Luar Negeri, 2015). Dari kelima poin tersebut, diplomasi ekonomi muncul sebagai istilah baru yang diberitakan di media sehingga akrab di telinga masyarakat. Diplomasi ekonomi Indonesia dipahami sebagai upaya mengedepankan kepentingan ekonomi dalam menjalankan politik luar negerinya.

Kementerian Luar Negeri secara spesifik membentuk satuan tugas pelaksana diplomasi ekonomi, yang bertugas untuk: 1) menarik lebih banyak investasi asing ke Indonesia; 2) membuka 
pasar yang lebih besar di luar negeri bagi komoditas produk Indonesia; dan 3) menumbuhkan jumlah turis asing datang ke Indonesia. Haryono (2019) menjelaskan bahwa dalam pidato-pidato presiden dalam bidang politik luar negeri dan penjelasan menteri luar negeri secara eskplisit sering menekankan investasi dan perdagangan. Langkah-langkah di atas juga diiringi dengan implementasi pada tingkat nasional untuk membangun kepercayaan pihak asing terhadap kesungguhan pemerintah Indonesia. Membuka lebih banyak sektor ekonomi untuk investasi, menyiapkan infrastruktur ekonomi dan industri, dan meningkatkan pendidikan nasional perlu dihiraukan untuk menarik lebih banyak investasi asing (Haryono, 2019).

Sebagai anggota G20, Kemenlu (2015) menyatakan bahwa dalam setiap KTT G-20, Indonesia senantiasa berperan dalam memajukan kepentingan negara berkembang dan menjaga terciptanya sistem perekonomian global yang inklusif dan berkelanjutan. Artinya, Indonesia membangun citranya sebagai perwakilan negara emerging economies, yang berkesempatan mendapatkan global leadership role (Dobson, 2017). Ditambah sebagai satu-satunya negara dari regional Asia Tenggara, Indonesia juga menjadi salah satu negara dari enam negara dari regional Asia yang terpilih dalam forum istimewa G20. Namun, tentu saja kepentingan nasional tetap menjadi perhatian terbesar dari Indonesia.

Sebagai negara yang kekuatan ekonominya berasal dari perdagangan, salah satu upaya yang dilakukan Indonesia untuk meningkatkan kapasitas perdagangannya adalah dengan mengurangi tingkat kemiskinan selain dengan meningkatkan daya saing di tengah liberalisasi ekonomi. Hal ini dilakukan dengan meningkatkan produktivitas industri manufaktur karena bukan hanya dapat meningkatkan kompetensi sumber daya manusianya tetapi juga memberi value-added (Legowo-Zipperer, 2017). Demi hal tersebut, Indonesia kemudian berfokus dalam mengundang investasi ke dalam negeri khususnya pada sektor infrastruktur.

Salah satu fokus diplomasi ekonomi Indonesia adalah penguatan diplomasi demi perluasan pasar prospektif, promosi perdagangan, pariwisata, dan investasi Indonesia. Pada periode pertama pemerintahan Jokowi, Indonesia tercatat mampu mencapai target investasinya (Tabel 1). Selama tahun 2015-2018, realisasi investasi hanya satu kali berada di bawah target, yakni pada tahun 2018. Sebagai negara emerging economies, Indonesia membutuhkan investasi untuk menggerakkan pembangunan ekonomi nasional. Langkah strategis yang diambil Indonesia adalah menentukan sektor prioritas investasi, menyelaraskan pembangunan nasional dengan sektor prioritas tersebut, memperbaiki iklim investasi, termasuk mengurangi biaya politik yang tinggi di Indonesia. 
Tabel 1. Target dan Realisasi Investasi Indonesia

\begin{tabular}{ccc}
\hline Tahun & Target (triliun Rupiah) & Realisasi (triliun Rupiah) \\
\hline $\mathbf{2 0 1 5}$ & 519,5 & 545,4 \\
\hline $\mathbf{2 0 1 6}$ & 594,8 & 612,8 \\
\hline $\mathbf{2 0 1 7}$ & 678,8 & 692,8 \\
\hline $\mathbf{2 0 1 8}$ & 765,0 & 721,3 \\
\hline
\end{tabular}

Sumber: (BKPM, 2019)

Selanjutnya, upaya di tingkat nasional tersebut dipromosikan melalui fora internasional, termasuk di G20. Salah satu contoh capaian Indonesia adalah pada tahun 2014, yang setelah tiga tahun, usulan Indonesia berhasil diterima menjadi agenda G20 terkait aliran dana investasi infrastruktur yang berasal dari negara maju kepada negara berkembang. Saat itu, Indonesia bersama dengan Jerman dan Meksiko ditetapkan menjadi Kepala Investment and Infrastructure Working Group (IIWG) G20 (Ariyanti, 2014). Salah satu hal yang menjadi perhatian negara maju terkait hal ini adalah perlunya perbaikan iklim investasi dan pembenahan administrasi yang ada di negara berkembang.

Tabel 2. Tingkat Pertumbuhan PDB Negara G20

\begin{tabular}{lrrrrrr}
\hline Country & $\mathbf{2 0 1 4}$ & $\mathbf{2 0 1 5}$ & $\mathbf{2 0 1 6}$ & $\mathbf{2 0 1 7}$ & $\mathbf{2 0 1 8}$ & $\mathbf{2 0 1 9}$ \\
\hline Australia & 2,6 & 2,3 & 2,8 & 2,5 & 2,8 & 1,8 \\
\hline Canada & 2,9 & 0,7 & 1,0 & 3,2 & 2,0 & 1,7 \\
\hline France & 1,0 & 1,1 & 1,1 & 2,3 & 1,8 & 1,5 \\
\hline Germany & 2,2 & 1,7 & 2,2 & 2,5 & 1,5 & 0,6 \\
\hline Italy & $-0,0$ & 0,8 & 1,3 & 1,7 & 0,8 & 0,3 \\
\hline Japan & 0,4 & 1,2 & 0,5 & 2,2 & 0,3 & 0,7 \\
\hline Korea & 3,2 & 2,8 & 2,9 & 3,2 & 2,9 & 2,0 \\
\hline Mexico & 2,8 & 3,3 & 2,6 & 2,1 & 2,2 & $-0,3$ \\
\hline Turkey & 5,2 & 6,1 & 3,2 & 7,5 & 2,8 & 0,9 \\
\hline United Kingdom & 2,6 & 2,4 & 1,9 & 1,9 & 1,3 & 1,5 \\
\hline United States & 2,5 & 2,9 & 1,6 & 2,4 & 2,9 & 2,3 \\
\hline European Union $-\mathbf{2 7}$ countries & 1,6 & 2,4 & 2,1 & 2,7 & 2,1 & 1,5 \\
(from 01/02/2020) & & & & & & $-2,6$ \\
\hline Argentina & $-2,5$ & 2,7 & $-2,1$ & 2,8 & $-2,1$ \\
\hline Brazil & 0,5 & $-3,5$ & $-3,3$ & 1,3 & 1,3 & 1,1 \\
\hline China (People's Republic of) & 7,3 & 6,9 & 6,7 & 6,8 & 6,6 & 6,1 \\
\hline India & 7,0 & 7,5 & 9,0 & 6,6 & 6,8 & 4,9 \\
\hline Indonesia & $\mathbf{5 , 0}$ & $\mathbf{4 , 9}$ & $\mathbf{5 , 0}$ & $\mathbf{5 , 1}$ & $\mathbf{5 , 2}$ & $\mathbf{5 , 0}$ \\
\hline Russia & 0,7 & $-2,0$ & 0,2 & 1,8 & 2,5 & 1,3 \\
\hline Saudi Arabia & 3,7 & 4,1 & 1,7 & $-0,7$ & 2,4 & 0,3 \\
\hline South Africa & 1,8 & 1,2 & 0,4 & 1,4 & 0,8 & 0,2 \\
\hline S & & & & & &
\end{tabular}

Sumber : (OECD, 2020) 
Ditinjau dari pertumbuhan PDB negara G20, Indonesia merupakan salah satu negara yang teratas yang stabil dan cenderung mengalami peningkatan 5\% tiap tahunnya (Tabel 2). Stabilnya pertumbuhan ekonomi Indonesia menjadi senjata bagi Indonesia dalam forum G20 guna mengundang minat investasi infrastruktur di dalam negeri. Kemampuan Indonesia dalam mempertahankan pertumbuhan ekonominya diatas 5\% juga dapat menjadikan hal ini sebagai bukti bahwa Indonesia layak dan mampu untuk mengadvokasikan kebijakan yang berkualitas dan mengarah pada pertumbuhan inklusif untuk kemudian diadopsi oleh negara G20.

Dalam RPJMN 2015-2019, lebih jauh dinyatakan bahwa dalam G20, Indonesia perlu untuk melaksanakan koordinasi kebijakan yang lebih erat antara negara anggota demi menjaga sistem perekonomian global yang berkelanjutan. Upaya koordinasi yang dilakukan Indonesia dalam G20 merupakan salah satu cerminan diplomasi komersial Indonesia, yang mana Indonesia secara konsisten memperbaiki persepsi atau pandangan negara anggota G20 mengenai Indonesia. Upaya Indonesia untuk mendorong pertumbuhan ekonomi nasional mencitrakan kepentingan bisnis yang ingin dicapai. Kekuatan ekonomi Indonesia, diiringi dengan pemetaan industri dan kesempatan investasi yang baik yang dipromosikan Indonesia dalam G20 menjadi strategi untuk membangun fondasi efektif bagi para pelaku bisnis nasional. Dengan demikian, kepercayaan investor terus terbangun terhadap Indonesia.

Lebih jauh, kepentingan komersial dalam keanggotaan Indonesia di G20 juga didukung oleh outreach group yang disebut "The Business 20" (B20). B20 adalah komunitas bisnis yang merefleksikan peran sektor swasta dalam menumbuhkan ekonomi nasional maupun global. Pertemuan B20 Summit selalu menjadi bagian penting dari KTT G20. Dalam pertemuan tersebut, para pelaku usaha dari 20 negara anggota G20 berkumpul untuk bersinergi dalam membuka jalan membangun ekonomi global. Dalam rekomendasi B20, negara diharapkan mampu memfasilitasi pasar, meningkatkan peran bank pembangunan multilateral dalam pembangunan infrastruktur, serta mempromosikan inklusi keuangan melalui teknologi digital. Dengan demikian, kepentingan finansial juga menjadi sorotan penting bagi para pelaku usaha yang notabenenya adalah penggerak roda ekonomi nasional.

Bagaimanapun, pembentukan rezim G20 merupakan bentuk kesadaran negara-negara maju atas peranan negara-negara berkembang terhadap kestabilan ekonomi dunia. Keanggotaan G20 terdiri atas negara-negara industri yaitu sembilan negara dan organisasi regional: Amerika Serikat, Inggris, Perancis, Jepang, Jerman, Kanada, Italia, Korea Selatan, Australia, Uni Eropa, serta 
sepuluh negara berkembang yang dikategorikan sebagai emerging economies, yaitu: Rusia, Argentina, Brazil, China, India, Indonesia, Mexico, Saudi Arabia, Afrika Selatan, Turki. Dalam kelompok rezim G20, negara-negara anggotanya berusaha untuk menghindari proteksionisme dan menstabilkan sistem keuangan global. Gilpin (2000) menyebutkan bahwa hubungan antara negara maju dan negara berkembang akan sangat bergantung kepada bertahannya ekonomi industrial yang lama atau berkembangnya sistem ekonomi menjadi lebih inovatif dan mampu meraih keuntungan yang sebanding dalam wilayah-wilayah baru seperti kemampuan ekspor-impor. Untuk menghindari ketegangan ekonomi dan konflik politik, masing-masing pihak harus membuat kompromi satu sama lain dan tidak boleh menggunakan kebijakan proteksionis kecuali sebagai tindakan sementara.

Diplomasi dan negosiasi Indonesia di G20 itu seperti memasuki dunia game. Zartman (2007) menyebutnya sebagai diplomasi game, negara-negara harus mampu menempatkan posisi strategisnya untuk menentukan daya tawar. Negara -negara harus menyusun puzzle yang terpisahpisah agar bisa bersatu dan mencapai kesepakatan. Hal inilah yang dilakukan Indonesia dalam hubungan multilateral di G20 Indonesia harus pandai memposisikan dirinya sebagai negara yang bisa melengkapi semua kebutuhan negara lain dan dilengkapi kebutuhannya oleh negara lain.

\section{Diplomasi Ekonomi Indonesia di dalam Rezim G20}

Pada bagian ini, konteks diplomasi ekonomi akan dikhususkan kepada konsep diplomasi komersial; diplomasi perdagangan, dan diplomasi finansial yang dikemukakan oleh Lee \& Hocking (2010). Diplomasi komersial berfokus pada membangun jaringan diplomat dan kelompok bisnis yang berbasis di misi luar negeri untuk mempromosikan perdagangan dan investasi serta advokasi bisnis. Secara konseptual, studi diplomasi komersial menunjukkan jaringan organisasi yang kompleks yang melibatkan Kementerian Perdagangan, Kementerian Keuangan, dan Kementerian Luar Negeri. Disamping itu, kelompok bisnis menjadi pemain kunci dalam jaringan ini dan dalam banyak kasus secara resmi ditempatkan dalam misi dan konsul di luar negeri melalui program penugasan. Strange (1992) berargumen bahwa perusahaan asing telah berperan sebagai diplomat, khususnya dalam sektor keuangan dan industri dalam suatu negara. perusahaan asing saat ini dipandang sebagai suatu tambahan yang berarti ke dalam instrumen kebijakan negara.

Selanjutnya, terkait diplomasi perdagangan, ekonomi dunia sekarang telah diatur oleh seperangkat institusi ekonomi dengan aturan dan prosedur. Dengan penciptaan WTO pada tahun 
1995, perdagangan antar negara semakin diatur oleh aturan internasional yang harus dinegosiasikan dan diimplementasikan. Peran negara dalam konteks melakukan negosiasi dalam perjanjian perdagangan tentu masih bersifat signifikan. Meskipun konsep firm-firm diplomasi telah dimunculkan oleh Strange, namun diplomasi yang dilakukan oleh diplomat yang menjadi perwakilan resmi dari negara menjadi kunci penting dalam pelaksanaan diplomasi perdagangan.

Selaras dengan hal itu, diplomasi finansial menjadi perhatian utama bagi negara yang menginginkan kestabilan finansial baik nasional maupun global. Hasil karya dari G7, G8, IMF dan Bank Dunia memposisikan negara menjadi aktor sentris terhadap diplomasi keuangan (Bayne 1998; Budd 2003; Kirton 1999; Wicks 2007 dalam Lee \& Hocking, 2010). Banyak studi yang berargumen bahwa diplomasi finansial secara konsep berkeembang seiring dengan kejadian krisis keuangan yang senantiasa terjadi. Kelompok rezim ekonomi G20 merupakan bentuk integrasi ekonomi yang terjalin antara negara maju dan negara berkembang. Gilpin (2000) berargumen bahwa integrasi ekonomi negara berkembang terhadap perekonomian dunia akan menciptakan pertumbuhan ekonomi dan level produksi. Tingkat pertumbuhan ekonomi yang cepat akan cenderung 'mengangkat semua perahu' dalam masyarakat dan, pada waktunya, akan menguntungkan bagi semua. Memang, sebagian besar ekonom Amerika dan komentator lain percaya bahwa negara berkembang akan mengadopsi model Amerika dari ekonomi berorientasi pasar dan bahwa globalisasi akan meningkatkan penerimaan dunia terhadap individualisme dan demokrasi politik.

Pada dasarnya, melalui pertemuan berkala, para pemimpin G20 telah mengadopsi prinsip kehati-hatian (prudence) setiap kali mereka memperkenalkan kebijakan ekonomi, karena kebijakan tersebut dapat berdampak negatif pada ekonomi negara lain (Hermawan Y. P., 2017). Melalui prinsip tersebut, aktivitas diplomasi ekonomi menjadi penting bagi pembuatan kebijakan.

Bagi Indonesia, tentu G20 menyimpan sejumlah kepentingan strategis. G20 merupakan forum yang mementingkan permasalahan ekonomi khususnya perdagangan, investasi dan pembangunan infrastruktur. Maka dari itu, melalui G20, Indonesia diharapkan akan mengalami akselerasi pertumbuhan ekonomi, khususnya di sektor pembagunan infrastruktur (Hermawan Y. P., 2017). Sejak pelantikannya sebagai Presiden, Jokowi tidak pernah absen menghadiri KTT G20. Hal ini mencerminkan forward-thinking perspektif Jokowi yang menyadari pentingnya G20 sebagai platform strategis untuk pencapaian visi nasionalnya. 
Posisi strategis Indonesia di G20 menentukan implementasi kebijakan luar negeri Indonesia di bidang ekonomi dalam diplomasi ekonomi. Dalam Nawa Cita dan RPJMN dijelaskan Indonesia memiliki 5 orientasi kebijakan luar negeri yakni: a) keamanan dan perdamaian, b) perlindungan warga negara Indonesia di luar negeri, c) diplomasi ekonomi, d) kerja sama ASEAN, dan e) diplomasi maritim (Fitriani \& Panduwinata, 2018). Dalam implementasi diplomasi ekonomi Indonesia sebagai pilar politik luar negerinya tentunya memiliki strategi-strategi komprehensif untuk mencapai kepentingan tersebut. John Lovel (Masoed, 1994) menyampaikan akan pentingnya strategi dalam implementasi politik luar negeri. Ada empat strategi yang diterapkan yakni konfrontasi, korkondansi, leadership dan akomodasi. Indonesia memiliki dua komponen yakni korkondansi dan akomodasi. Diplomasi Indonesia dilakukan dengan kreatif, aktif, antisipatif, transparan luwes sesuai dengan amanat konstitusi Indonesia sesuai UU/37/1999.

Praktik operasional konsep diplomasi ekonomi di bawah Pemerintahan Presiden Jokowi jelas menekankan diplomasi ekonomi dengan lebih sentral dalam kebijakan luar negeri Indonesia. Pola ini menjadikan karakter diplomasi Indonesia yang selalu mendesain pola program dalam kepentingan bersama. Alasannya, dengan memperkuat diplomasi ekonomi mengarah untuk mendukung pertumbuhan ekonomi negara dan mempromosikan kemakmuran nasional. Penekanan diplomasi ekonomi dalam kebijakan luar negeri Indonesia dengan jelas disebutkan dalam Rencana Strategis Kementerian Luar Negeri Republik Indonesia untuk periode 2015-2019. Namun, dalam praktiknya, Sabaruddin (2016) mengakui bahwa Presiden Jokowi lebih menekankan pada pentingnya meningkatkan kinerja diplomasi komersial dan perdagangan Indonesia, khususnya dalam mempromosikan ekspor (terutama ekspor non-minyak) dan termasuk memperkuat misi perdagangan Indonesia yang akan keluar. Artinya program itu dirancang dalam kebijakan strategis yang kemudian dikomunikasikan baik di level bilateral, regional dan global.

Dalam Rencana Strategis 2015-2019 Kementerian Luar Negeri Republik Indonesia dimuat bahwa posisi Indonesia sebagai satu-satunya negara di Asia Tenggara yang menjadi anggota G20 memotivasi Indonesia agar berperan aktif dalam upaya penanganan krisis ekonomi global dan mendorong reformasi tata kelola ekonomi dunia. Oleh karena itu diplomasi Indonesia di G20 perlu memperkuat kepentingan ekonomi nasional untuk mendukung pertumbuhan ekonomi Indonesia yang berkualitas atau (growth with equity). Diplomasi Indonesia untuk mendukung quality growth atau growth with equity tersebut sejalan dengan kepentingan negara berkembang (Kementerian 
Luar Negeri, 2015). Fakta konkret diplomasi Indonesia dalam implementasi politik luar negerinya dengan melahirkan Diplomasi 4+1 yang disampaikan Menlu Retno Marsudi pada akhir 2019.

Lebih lanjut, Menlu Retno Marsudi menyampaikan orientasi politik luar negeri Indoesia melalui diplomasi 4+1 (Kementerian Luar Negeri, 2019). Diplomasi ini meliputi penguatan diplomasi ekonomi; diplomasi perlindungan; diplomasi kedaulatan dan kebangsaan; dan peran Indonesia di kawasan dan global. Sementara plus satu-nya adalah penguatan infrastruktur diplomasi. Secara rinci, prioritas untuk memperkuat diplomasi ekonomi telah disiapkan yang terdiri dari enam langkah strategis. Penelitian ini menyoroti keenam langkah strategis dalam diplomasi ekonomi Indonesia di G20 ini

Pertama, kapitalisasi penguatan pasar domestik. Argumentasi poin ini adalah Indonesia sebagai negara besar dengan jumlah penduduk mencapai 250 juta lebih adalah peluang kerja sama bilateral, regional dan global untuk menggaet konsumen dalam negeri. Langkah strategis ini dilakukan Jokowi dalam diplomasi di forum G20. Akselerasi diplomasi ekonomi sebagai pilar politik luar negeri Indonesia terlihat pada KTT G20 Antalya Tukri pada 15 November 2015. Walaupun karakter diplomasi Jokowi lebih menggunakan pendekatan bilateralisme namun Jokowi memahami pentingnya isu ekonomi dan politik untuk saling bersinergi. Dua pertemuan penting yang dilakukan Jokowi adalah bertemu dengan Perdana Menteri Kanada Justin Trudeau. Pada pertemuan tersebut Jokowi membicarakan pentingnya kerjasama kedua negara dalam bidang ekonomi. Jokowi meminta Kanada tetap menjadi pasar produk-produk Indonesia serta mendorong peningkatan sumberdaya dan investasi serta infrastruktur. Selain itu, pertemuan G20 kembali menjadi ajang bilateralisme Jokowi dengan bertemu Presiden Tiongkok Xi Jing Ping. Kedua kepala negara membicarakan isu diplomasi ekonomi dalam bidang perbankan, yang Tiongkok siap membantu pembangunan infrastruktur di Indonesia melalui bank-bank Tiongkok menjadi 20 milyar USD. Pertemuan berikutnya adalah KTT G20 tahun 2016 yang dilaksanakan di Tiongkok dengan Jokowi menjadi pembicara kunci dalam KTT tersebut. Dalam pertemuan itu, Jokowi menyerukan diplomasi perdagangan dengan menyampaikan gagasan bahwa pentingnya kerjasama antara negara dengan tidak melakukan proteksi tarif dan non-tariff dalam perdagangan internasional. Jokowi juga menyerukan untuk melakukan investasi di Indonesia serta membangun UMKM. Di sela pertemuan multilateral Jokowi kembali bertemu Presiden Tiongkok untuk membicarakan dukungan Indonesia dalam program OBOR yang selaras dengan Poros Maritim Dunia. Selain itu, dalam pertemuan G20 tahun 2017 yang dilaksanakan di Jerman Jokowi 
membahas tentang isu terorisme dan ekonomi. Namun disela-sela pertemuan multilateral ternyata Jokowi kembali melakukan pertemuan bilateral dengan Presiden Amerika Serikat yang membahas tentang Amerika dapat menjadi pasar biodisel Indonesia. Pembicaraan isu ekonomi ini tentunya menguntungkan kedua negara (Rosyidin, 2019).

Langkah strategis kedua, penguatan pasar tradisional dan terobosan pasar non-tradisional. Pada poin ini selain mengutamakan dan tetap membangun relasi ekonomi tradisional seperti Eropa, Amerika, Tiongkok, Indonesia juga membidik Afrika sebagai pasar non-tradisional melalui kemitraan Indonesia-Africa Forum dan Indonesia-Africa Infrastructure Dialogue. Kemitraan Indonesia dan Afrika sudah terjalin sejak lama. Hal ini terlihat ketika Konferensi Gerakan NonBlok yang disponsori oleh Indonesia dan kemitraan ini semakin erat ketika Indonesia menjadi tuan rumah Konferensi Asia Afrika pada tahun 2015. Salah satu peran Indonesia untuk menjadikan Afrika sebagai pasar non-tradisional terlihat dalam KTT G20 yang dilaksanakan di Jerman pada tahun 2017. Pidato Jokowi menyampaikan bahwa Indonesia dan Afrika memiliki kemitraan sejarah kemerdekaan sejak Konferensi Asia Afrika tahun 1955. Dalam pertemuan Leaders Retreat KTT G20, Jokowi juga menyampaikan bahwa G20 harus bermitra dengan Afrika atau G20 Africa Partnertship dengan target capaian 2063 melalui G20 Compact with Africa (Tempo.co, 2017).

Jika melihat Konferensi Asia Afrika yang dilaksanakan di Bandung dan Jakarta pada tanggal 19-23 April 2015 sekaligus memperingati 60 tahun kerjasama konfrensi Asia Afrika, konfrensi tersebut memuat agenda berikut: (a) menelaah kembali dasasila bandung yang sudah dituliskan sebelumnya, (b) meningkatkan kembali kerjasama strategis negara-negara Asia Afrika, serta (c) mendukung deklarasi kemerdekaan Palestina. Pada poin (b) memiliki tiga pilar utama yakni (1) menyangkut komitmen politik untuk mendukung Palestina menjadi negara, reformasi PBB, perdamaian internasional serta penguatan kerjasama regional kawasan, (2) pada pilar ini menjadi perbedaan arah kebijakan luar negeri Jokowi yakni penguatan kerjasama maritim, seperti yang diinginkan Jokowi, untuk menjadi poros maritim dunia (blue economic power), menggiatkan konektivitas serta mobilisasi bisnis, dan (3) berhubungan dengan sosial budaya, seperti gender, diplomasi bencana, migrasi, pemuda. Pada pertemuan tersebut juga terjadi Reinvigorating the New Asian-African Strategic Partnership (NAASP) yang ditetapkan pada tahun 2005. Kerjasama utamanya dengan delapan fokus NAASP seperti terorisme, organisasi kejahatan transnasional, keamanan pangan, keamanan energi, kerjasama universitas (Fathun, 2017). 
Langkah strategis diplomasi ekonomi Indonesia yang ketiga adalah penguatan perundingan perdagangan dan investasi. Pada upaya ini Indonesia meningkatkan kerja sama komprehensif seperti Comprehensive Economic Partnership Agreement (CEPA), Free Trade Agreement (FTA), Preferential Trade Agreement (PTA). Mitra kerja sama tersebut adalah peluang Indonesia dalam menjalin dan membuka peluang investasi untuk mendapatkan pemasukan negara yang besar. Kemitraan ini merupakan bagian penting untuk terus mengasah progesivitas diplomasi Indonesia pada saat negara lain pertumbuhan ekonominya stagnan. Misalnya di forum G20 masih sangat menarik bagi Indonesia. Keterlibatan Indonesia pada tahun 2018 atau KTT G20 yang dilaksanakan di Argentina. Uniknya pada pertemuan ini Indonesia diwakili oleh Jusuf Kalla yang membicarakan beberapa hal di antaranya adalah kondisi ekonomi global yang berorientasi pada komitmen membangun ekonomi yang kuat, berkesinambungan, seimbang dan inklusif dengan tercapainya inklusi perdagangan yang adil, transparan, rule based, non diskriminatif, dan pembentukan sistem pajak perdagangan yang efisien. Selain itu, Jusuf Kalla juga bertemu dengan Presiden Turki dan Putra Mahkota Arab Saudi. KTT ini dengan tema building consencus tentunya membawa isu-isu ekonomi untuk menjaga stabilitas ekonomi global (Rosyidin, 2019). Pertemuan KTT G20 Argentina ini menjadi fondasi pertemuan G20 berikutnya di Osaka Jepang. Pada kesempatan tersebut, ketika membahas tentang isu kerja sama ekonomi, Jokowi kembali melakukan diplomasi bilateralisme dalam bidang perdagangan dan investasi dengan Korea Selatan. Pertemuan ini menjadi lanjutan pertemuan tahun 2018 tepatnya pada bulan September. Kedua negara berkomitmen membangun iklim investasi dan perdagangan melalui Indonesia-Korea Comprehensive Economic Partnership Agreement atau IKCEPA (Kompas.com, Di KTT G20, Ini 5 Topik Ekonomi yang Dibahas Presiden Jokowi, 2019). Pertemuan tersebut tentunya akan menguntungkan kemitraan strategis ekonomi yang inklusif, transparan, dan efisien.

Langkah keempat, promosi terpadu perdagangan dan investasi serta mendorong outbound investment. Pada poin Indonesia berupaya memaksimalkan Bilateral Investment Treaty dengan melakukan koordinasi dengan beberapa stakeholders seperti BUMN, BUMD, kementerian dan lembaga terkait. Hal ini untuk menciptakan iklim investasi yang nyata dengan produk-produk pengolahan yang mampu bersaing di pasar regional dan global. Jokowi yang selalu menyampaikan bahwa setiap pertemuan Indonesia harus memiliki manfaat. Diplomat Indonesia harus menjadi 'sales' yang mampu membawa investor masuk ke Indonesia. Hal tersebut kemudian dibuktikan dengan penguatan kerjasama antara BKPM dan Kemlu untuk menggenjot investasi. Kedua 
lembaga mengakui pentingnya peran perwakilan Indonesia di luar negeri sebagai aktor strategis dalam diplomasi ekonomi. Memanfaatkan keanggotaannya di G20, Indonesia pun secara konsisten mengangkat isu investasi di forum ini. Dapat dilihat pada KTT G20 Buenos Aires 2018, Indonesia menyebutkan adanya tiga strategi utama untuk menarik investasi jangka panjang berkelanjutan, yaitu 1) kebijakan publik yang dirancang secara baik dan stabil demi kepastian hukum dan investasi, 2) menjaga reputasi pemerintah sebagai institusi publik yang dipercaya (trusted), 3) pemerintah harus memiliki dan menguasai risiko politik yang sering terjadi negara berkembang. Secara praktis, Indonesia mempromosikan perihal online single window untuk investasi, insentif fiskal melalui tax holiday dan tax allowance, serta sejumlah deregulasi untuk mendorong pembangunan infrastruktur (BKPM, 2018).

Selanjutnya, langkah kelima adalah menjaga kepentingan strategis ekonomi Indonesia. Pada poin ini Indonesia berupaya menciptakan iklim invetasi dan ekspor impor non-diskriminasi. Hal ini berhubungan dengan menguatnya diskriminasi produk sawit atau CPO Indonesia di Uni Eropa. Hal tersebut tentunya bertentangan dengan prinsip pasar bebas yang memberikan keleluasaan setiap negara untuk mengirimkan ekspor produknya asalkan sesuai dengan kriteria pengimpor bukan terbatas pada hambatan ekspor tarif dan non tarif. CPO merupakan sumber pendapatan bagi 6 juta rakyat Indonesia sehingga sektor ini sangat strategis bagi Indonesia. Pasca dikeluarkannya resolusi sawit dan larangan biodiesel berbasis kelapa sawit oleh Parlemen Uni Eropa, Menteri Perdagangan Indonesia segera menyatakan akan mengambil langkah melalui forum G20 (Kompas.com, 2017). Secara konkret, pada KTT G20 Osaka 2019, pemerintah Indonesia menyampaikan komitmen terkait transisi energi dan perlindungan lingkungan hidup. Melalui pertemuan tingkat menteri di G20, Menteri Energi dan Sumber Daya Mineral dan Menteri Kehutanan dan Lingkungan Hidup berhasil menyepakati komunike energi G20. Komitmen tersebut menggambarkan bahwa Indonesia telah berhasil menyampaikan perkembangan dan capaian program biofuel sehingga dapat diterima negara anggota G20 menjadi bagian energi terbarukan untuk dipakai di negara mereka (2019).

Terakhir, yaitu langkah strategis keenam yang mendukung diplomasi ekonomi Indonesia yaitu, mendorong ekonomi 4.0 yang meliputi industri digital, ekonomi kreatif dan pengembangan SDM Indonesia. Kebijakan ini diperlukan untuk meningkatkan produktivitas berbagai industri di Indonesia, maupun membuka akses bagi kelompok menengah ke bawah di pasar internasional, inklusi keuangan, dan ekonomi kreatif, sehingga pertumbuhan ekonomi nasional akan semakin 
tinggi dan rata. Berkaitan dengan visi pembangunan ekonomi inklusif Presiden Jokowi, di KTT G20 di Osaka 2019 Indonesia mengkonseptualisasikan IDEA Hub sebagai platform global untuk pelaku bisnis digital, terutama yang telah mencapai status unicorn, untuk mengumpulkan ide dan berbagi pengalaman mereka yang diharapkan bermanfaat bagi pemerintah, sektor swasta, dan usaha mikro, kecil, dan menengah (UMKM). Inisiatif tersebut diusulkan dalam upaya untuk mengurangi kesenjangan ekonomi dan sosial di antara negara-negara. Lebih jauh, dalam poin 1012 Leaders Declaration G20, telah disepakati Innovation: Digitalization, Data Free Flow with Trust yang bersifat mendukung visi Presiden Jokowi. Transformasi ini menjadi komitmen Indonesia untuk aktif berperan menciptakan ekonomi yang kompetitif. Artinya Indonesia mampu mengkomunikasikan hasil pemikirannya sehingga berbentuk deklarasi. Adanya deklarasi tersebut menjadi bukti kuat bahwa Indonesia bukan hanya menjadikan transformasi ekonomi digital sebagai komitmen nasional tetapi juga menghimbau negara-negara di G20 untuk bersama-sama membangun ekonomi berbasis teknologi.

Presiden Jokowi senantiasa menegaskan pentingnya bersikap inklusif dalam era ekonomi digital di berbagai fora internasional seperti G20. Salah satu contoh isu prioritas yang sering digaungkan oleh pemerintah Indonesia adalah roadmap kebijakan e-commerce, khususnya bagi UMKM, untuk mendukung pengembangan e-commerce. Jadi, roadmap pembangunan ekonomi yang inklusif bagi Indonesia adalah dengan menggunakan platform digital. Pemahaman ekonomi inklusif bagi Jokowi adalah bukti komitmen untuk mendesain ekonomi yang komprehensif di era digital. Indonesia berkomitmen untuk menjaga stabilitas ekonomi nasional, regional dan global melalui kerja sama G20. Itu artinya setelah Indonesia mampu mendesain kebijakan strategisnya Indonesia mengomunikasikan komitmen tersebut dengan upaya memfasilitasi pebisnis global untuk berdagang, berinvestasi dan menanamkan modalnya di Indonesia. Sebagai mahluk rasional negara tentunya tidak bisa hidup sendiri apalagi dengan posisi sebagai negara demokrasi. Adapun keterbatasan tersebut adalah menyangkut tiga poin. Poin pertama, kemampuan sumber daya yang menyangkut sumber daya manusia dan sumber daya produksi. Indonesia barangkali memiliki sumber daya produksi yang banyak namun kelemahannya belum tentu kompetitif, produktif, dan inklusif. Selain itu dari segi sumber daya manusia belum bisa bersaing untuk menciptakan tenaga kerja yang cepat, unggul dan efisien. Hampir sebagain besar tenaga kerja ahli berasal dari negara lain. Poin berikutnya, kemampuan teknologi di era digital untuk menciptakan ekonomi yang inklusif bagi kreativitas pola ekonomi harus fleksibel termasuk menggunakan teknologi informasi. 
Lahirnya pola ekonomi digital akan menjadi peluang besar bagi Indonesia untuk bisa ikut membangun ekonomi global. Poin terakhir adalah ketersediaan anggaran dan tata kelola ekonomi. Pada poin ini adalah Indonesia tentunya memiliki keterbatasan anggaran untuk mengelola sumber produksi yang inklusif. Dengan adanya diplomasi perdagangan dan komersial menjadikan peluang buat Indonesia untuk memperoleh dana dan devisa hasil perdagangan dengan mitra negara. Selain itu, beberapa hambatan tata kelola baik tarif dan non-tarif bisa saja menjadi penghalang karakter diplomasi ekonomi Indonesia. Banyaknya aturan investasi, penanaman modal akan menghambat masuknya donor ke Indonesia.

Berdasarkan analisis langkah strategis diplomasi ekonomi Indonesia, penelitian ini melihat bahwa berdasarkan klusterisasi milik Rana, maka Indonesia dapat disebut berada dalam kluster evolving.

Tabel 2 - Tipologi Diplomasi Ekonomi Indonesia

\begin{tabular}{ll}
\hline Manajemen Ekonomi Eksternal & $\begin{array}{l}\text { Adanya koordinasi antara Kementerian perdagangan dan Kemlu; } \\
\text { persaingan dapat terjadi; Indonesia menunjukkan kolaborasi dan } \\
\text { koordinasi. }\end{array}$ \\
\hline Manajemen Kebijakan & $\begin{array}{l}\text { Inter-ministry atau koordinasi di tingkat kabinet; Sherpa G20 Indonesia } \\
\text { yang mengkoordinir hubungan antar kementerian dalam G20 }\end{array}$ \\
\hline Peran Non-State Actor & Prosedur baru, strong networking; Pertemuan B20 dalam agenda G20. \\
\hline Bantuan Economi: Recipient & $\begin{array}{l}\text { Networking antara instansi pengelola bantuan dan Kemlu; Agensi negara } \\
\text { penerima bantuan }\end{array}$ \\
\hline Bantuan Economi: Donor & $\begin{array}{l}\text { Program } \text { modest, biasanya meliputi kerjasama teknis; Penegasan oleh } \\
\text { Jokowi bahwa status Indonesia bukan negara recipient }\end{array}$ \\
\hline Promosi Perdagangan & $\begin{array}{l}\text { Perjanjian kerja sama, sering merupakan integrasi dari upaya politik dan } \\
\text { ekonomi; Indonesia mengikuti banyak working grup ataupun study grup } \\
\text { di G20. }\end{array}$ \\
\hline Promosi Investasi & $\begin{array}{l}\text { Kemlu dan keduataan bekerja secara aktif dengan instansi di dalam negeri, } \\
\text { sering berdasarkan inisiatif individu; Kerja sama aktif Kemlu dan BKPM }\end{array}$ \\
\hline Peran Diplomasi Regional & $\begin{array}{l}\text { Aktif; Indonesia menjadi negara representatif kawasan Asia Tenggara di } \\
\text { G20. }\end{array}$ \\
\hline
\end{tabular}

Oleh sebab itulah diplomasi ekonomi Indonesia mampu menunjang implementasi politik luar negeri Indonesia. Diplomasi ekonomi Indonesia di atas merupakan wadah atau arena bagi Indonesia untuk mencari kawan yang bisa dijadikan mitra strategis Indonesia dalam membangun stabilitas ekonomi. Indonesia menjadikan pertemuan-pertemuan tersebut sebagai arena menempatkan posisi untuk meningkatkan kualitas kepemimpinan nasional, regional dan global. Selain itu juga kerja sama di atas merupakan fondasi Indonesia untuk memperkuat dirinya sebagai negara yang memiliki kemampuan ekonomi yang bagus yang tergabung dalam G20 sebagai rezim 
ekonomi global. Artinya Indonesia mampu berperan secara global dalam meningkatkan stabilitas ekonomi nasional, regional dan global.

\section{Simpulan}

Penjelasan penulis memberi pengetahuan kepada pembaca bahwa Indonesia sebagai negara demokratis selalu mengambil posisi strategis untuk mewujudkan kepentingan ekonominya. Ekonomi menjadi domain penting dalam orientasi politik luar negeri Indonesia, sehingga ekonomi adalah upaya Indonesia terlibat dalam menstabilkan ekonomi nasional, regional dan internasional. Pola pemikiran ini sebagai bentuk rasionalitas negara modern yang mengkalkulasi setiap kontribusi melalui aksi. Perubahan ekonomi politik global tentu saja menuntut peran aktif dan adaptif dalam menjalin hubungan ekonomi dalam kerja sama internasional. Diplomasi ekonomi menjadi salah satu instrumen penting bagi Indonesia dalam mewujudkan kemakmuran Indonesia, sehingga kemampuan dalam berdiplomasi ekonomi merupakan hal yang krusial (Kementerian Luar Negeri, 2015).

Aksi Indonesia itu kemudian, dibuktikan dengan keterlibatan Indonesia di G20 sebagai upaya berkontribusi dalam ekonomi global. Orientasi ekonomi yang tinggi membuat diplomasi ekonomi adalah pilihan rasional bagi Indonesia untuk menjaga kepentinganya di luar negeri. Diplomasi ekonomi Indonesia digunakan sebagai upaya untuk mencapai kepentingan nasional dan internasional baik bidang perdagangan, investasi dan finansial. Dengan kolaborasi tiga bidang tersebut diharapkan bisa menjadi indikator menjaga stabilitas ekonomi Indonesia dan global serta sebagai upaya mencari mitra dan menjaga mitra Indonesia di luar negeri. Dengan demikian, upaya tersebut sebagai bentuk implementasi politik luar negeri Indonesia pada bidang ekonomi.

\section{Referensi}

Ariyanti, F. (2014, February 25). Usul Indonesia Sukses Diterima Negara G20. Diambil dari Liputan 6: https://www.liputan6.com/bisnis/read/2015267/usul-indonesia-suksesditerima-negara-g20

Baldwin, D. A. (1993). Neorealism and Neoliberalism: The Contemporary Debate. New York: Columbia University Press.

Bishop, M. L. (2019, June). Has the Multilateral Fightback Begun. Diambil dari Global Policy Journal: 
https://www.globalpolicyjournal.com/sites/default/files/Has\%20the\%20Multilateral\%20F ightback\%20Begun_0.pdf

BKPM. (2018). Tiga Strategi Indonesia Menarik Investor di Pertemuan G20. Retrieved from BKPM: $\quad$ https://www.bkpm.go.id/id/publikasi/detail/berita/tiga-strategi-indonesiamenarik-investor-di-pertemuan-g20

BKPM. (2019). Total Realisasi Investasi Tahun 2018 sebesar Rp 721,3 trilliun, Naik 4,1\%. Jakarta:

BKPM.

Retrieved

from https://www.bkpm.go.id/images/uploads/file_siaran_pers/Narasi_Bahasa_Indonesia_Pres s_Release_TW_IV_2018.pdf

Dobson, H. (2017). Asia in the G20: From Missed to Emerging Opportunity? Global Policy Global Leadership Initiative.

Fathun, L. M. (2017). Kebijakan Ideosinkretik (Wholistic) Joko Widodo (Jokowi) Dalam Konperensi Asia Afrika Tahun 2015. Dinamika Global, 2 No. 2, 42-67.

Fitriani, \& Panduwinata, V. C. (2018). Analisis Kinerja Kementerian Luar Negeri Indonesia (2015-2018). CSIS Working Paper Series.

Gilpin, R. (2000). The Challenge of the World Global Economy Capitalism in the 21st Century. New Jersey: Princeton University Press.

Haryono, E. (2019). Economic Diplomacy As Indonesian Foreign Policy Orientation In 20152018: Challenges And Opportunities. Global Strategis, Vol. 13 No. 2, 49-62.

Hermawan, Y. P. (2015). Quickwins dan Strategi Indonesia di G20 Mewujudkan Kemandirian Ekonomi dalam Konteks Ketidakpastian Global. Bandung: FISIP UNPAR.

Hermawan, Y. P. (2017). G20, Indonesia and the Quest for Parameters of Sustainable Infrastructure. Henrich Boll Stiftung Southeast Asia.

Hornung, M. (2017, 05 31). Indonesia's dilemma: The G20 and the United Nations' Sustainable Development Goals within a National Context. Retrieved from Heinrich Böll Foundation: https://www.boell.de/sites/default/files/e-paper_international_politics_g20_indonesia__baf.pdf

Jessop, B. (2016, March). The Changing Roles of States in Promoting \& Resisting Neoliberal Globalization. Journal of Ritsumeikan Social Sciences and Humanities, 7, 13-28.

Kementerian Luar Negeri. (2015). Renstra Kemenlu 2015-2019. Jakarta: Kemenlu.

Kementerian Luar Negeri. (2019, October 29). Penyampaian Prioritas Politik Luar Negeri 20192024 [Press Release]. Retrieved from Kementerian Luar Negeri: https://kemlu.go.id/

Kompas.com. (2017, April 10). Pemerintah Akan Bawa "Penjegalan" CPO oleh Uni Eropa ke Forum G20. Retrieved from Kompas: https://money.kompas.com/read/2017/04/10/202245026/pemerintah.akan.bawa.penjegala n.cpo.oleh.uni.eropa.ke.forum.g20

Kompas.com. (2019, Juni 30). Di KTT G20, Ini 5 Topik Ekonomi yang Dibahas Presiden Jokowi. Retrieved from Kompas: https://money.kompas.com/read/2019/06/30/110100626/di-kttg20-ini-5-topik-ekonomi-yang-dibahas-presiden-jokowi?page=all

Lee, D., \& Hocking, B. (2010). Economic Diplomacy. dalam R. A. (ed.), The International Studies Encyclopedia (pp. 1216-1227). Chichester: Wiley-Blackwell.

Legowo-Zipperer, V. (2017, July 07). Indonesia among the best economies in the G20. Diakses dari DW: https://www.dw.com/en/indonesia-among-the-best-economies-in-the-g20/a39598526

Masoed, M. (1994). Hubungan Internasional Disipilin dan Metologi. Jakarta: LP3S. 
OECD. (2019). OECD Technical Report on Progress on Structural Reform under the G20 Enhanced Structural Reform Agenda. Paris: OECD Publishing. Retrieved from oe.cd/g20esra-2019

OECD. (2020, July). G20 - Quarterly Growth Rates of GDP in volume. Retrieved from OECD Stats: https://stats.oecd.org/index.aspx?queryid=33940

Program Biofuel Diakui Dalam Pertemuan G20. (2019, Juli 5). Diakses dari Majalah Sawit Indonesia: https://sawitindonesia.com/program-biofuel-diakui-dalam-pertemuan-g20/

Rana, K. S. (2007). Economic Diplomacy: The Experience of Developing Countries. In N. B. Woolcock, The New Economic Diplomacy: Decision Making and Negotiations in International Relations (pp. 93-112). Surrey/Burlington: Ashgate. Retrieved from Kishan S. Rana: https://kishanrana.diplomacy.edu/

Reus-Smit, C., \& Snidal, D. (2008). The Oxford Handbook of International Relations. Oxford: Oxford University Press.

Rosyidin, M. (2019). Indonesia Menuju Kekuatan Global Abad 21 PolitikLuar NegeriIndonesia di Era Joko Widodo. Jakarta: Kompas Gramedia.

Sabaruddin, S. S. (2016). Grand Design Diplomasi Ekonomi Indonesia: Sebuah Pendekatan Indeks Diplomasi Ekonomi. Jurnal Ilmiah Hubungan Internasional, 12 No. 1, 69-90.

Strange, S. (1992). States, firms and diplomacy. International Affairs, 68(1), 1-15.

Sushanti, S. (2019). Indonesia dalam G20: Peluang atau Tren. Jurnal Ilmiah Widya Sosiopolitika, $1(1), 1-14$.

Tempo.co. (2017, Juli 9). Jokowi: Indonesia Dukung Peningkatan Kerja Sama G20 dengan Afrika. Retrieved from Tempo: https://nasional.tempo.co/read/889956/jokowi-indonesia-dukungpeningkatan-kerja-sama-g20-dengan-afrika

Wibisono, M. (2011, 10 05). Kerjasama Ekonomi Internasional: G20. Retrieved from ASEAN Foundation: $\quad$ http://www.aseanfoundation.org/documents/ed/2011/20111005_G20_ Intelstrat.pdf

Zartman, R. A. (2007). Diplomacy Game. New York: Springer. 